\title{
Genotoxical, teratological and biochemical effects of anthelmintic drug oxfendazole Maximum Residue Limit (MRL) in male and female mice
}

\author{
Aida El- MAKAWY, Hasnaa A. RADWAN, Inas S. GHALY, \\ A. Abd El-RAOUF \\ Cell Biology Department, National Research Center, Dokki, Giza, Egypt
}

(Received 30 May 2005; accepted 16 November 2005)

\begin{abstract}
Oxfendazole, methyl-5 (6)-phenylsulfinyl-2-benzimidazole carbamate, is a member of the benzimidazole family of anthelmintics. Anthelmintic benzimidazoles are widely used in meat producing animals (cattle, sheep and pigs) for control of endoparasites. The extensive use of veterinary drugs in food-producing animals can cause the presence of small quantities of the drug residues in food. Maximum residue limit or "MRL" means the maximum concentration of residue resulting from the use of a veterinary medicinal product which may be legally permitted recognized as acceptable in food. The FAO/WHO Expert Committee on Food Additives (1999) evaluations of toxicological and residue data, reported that oxfendazole (MRL) has toxicological hazards on human health. The toxicity of oxfendazole (MRL) was tested in male and female mice and their fetuses. Chromosomal aberrations, teratological examination and biochemical analysis were the parameters used in this study. The results show that oxfendazole MRL induced a mutagenic effect in all tested cell types. Also, oxfendazole exhibit embryotoxicity including teratogenicity. The biochemical results show that oxfendazole induced a disturbance in the different biochemical contents of all tested tissues. So, we must increase the attention paid to the potential risk of oxfendazole residues in human beings and should stress the need for careful control to ensure adherence to the prescribed withdrawal time of this drug.
\end{abstract}

anthelmintic / oxfendazole / maximum residue limit / genotoxicity / embryotoxicity / teratogenicity / biochemical changes

\section{INTRODUCTION}

Antiparasitic agents represent an important class in veterinary medicine. Among them, anthelmintic benzimidazoles are widely used in meat producing animals (cattle, sheep and pigs) for the control of endoparasites. Some members of this class of drugs have teratogenic and embryotoxic effects in animal species. In order to ensure human food safety, the European Union has set maximum residue limits (MRL) for benzimidazoles and their metabolites in animal products [1]. A Maximum Residue Limit or "MRL" means the maximum concentration of residue resulting from the use of a veterinary medicinal product which may be legally permitted recognized as acceptable

\footnotetext{
* Corresponding author: makawy2000@yahoo.com
} 
in food. This limit is either based on the type and amount of residue considered to be without any toxicological hazard for human health as expressed by the acceptable daily intake (ADI), or on the basis of a temporary ADI that utilizes an additional safety factor [2]. Liver, kidney, muscle and fat are the target tissues for residue control. MRL range from 10 to $1000 \mu \mathrm{g} \cdot \mathrm{kg}^{-1}$ depending on compound and matrix [1]. FAO/WHO Expert Committee on Food Additives [3] convened to evaluate the safety of residues of certain veterinary drugs in food and to recommend maximum levels for such residues. The Committee's evaluations of toxicological and residue data, reported that oxfendazole (MRL) has toxicological hazards on human health. Oxfendazole, methyl-5 (6)phenylsulfinyl-2-benzimidazole carbamate, is a member of the benzimidazole family of anthelmintics. It is the sulphoxide metabolite of fenbendazole and it is possible that fenbendazole owes much of its efficacy spectrum to oxfendazole. The probenzimidazole, febantel, when it is metabolized, also becomes fenbendazole, and finally oxfendazole, which is believed to be the active metabolite. The compound oxfendazole reaches peak blood levels more slowly following absorption from the intestinal tract than many of the older benzimidazoles, thereby maintaining effective concentrations for a longer time in both the serum and the intestinal tract increases its efficacy [4]. The heat stability of the anthelmintic oxfendazole in water, cooking oil and as incurred residues in cattle liver was investigated. It was found that cooking did not destroy residues although it may affect the point of equilibrium between oxfendazole, oxfendazole sulphone, fenbendazole and some other metabolites in incurred tissue [5]. The extensive use of veterinary drugs in food-producing animals can cause the presence of small quantities of the drug residues in food. Certain drugs can be carried over into the milk of lactating cows or deposited in the tissues of an animal intended for slaughter $[6,7]$. In recent years, there has been widespread and increasing con- cern that drugs, as well as environmental chemicals, may present a potential hazard to mankind by causing gene mutations or chromosome aberrations. Genetic alterations in somatic tissues can have a number of immediate effects upon the cells involved, including cell death or transformation into malignancy. Genetic alteration in germ cells leads to reproductive failure or genetic disorder in subsequent generations that include heritable mutations lowering the reproductive output of affected population [8]. So, the purpose of the present study was to evaluate the competence of oxfendazole maximum residue limit (MRL) on the incidence of genetic alteration in male and female mice and their teratogenic effect in embryos of treated parents.

\section{MATERIALS AND METHODS}

\subsection{Drug}

Tyvert, Oxfendazole $2.265 \%$ is a broad spectrum worm drench for cattle and sheep, manufactured by Pharmacia au Upjohn, Purs-Belgium. Oxfendazole CAS No. 53716-50-0. The dose equal to Oxfendazole maximum residue limit in liver $\left(1000 \mu \mathrm{g} \cdot \mathrm{kg}^{-1}\right)$ was used. Each animal gavages orally $0.01 \mathrm{~mL}$ daily.

\subsection{Assay of genotoxicity in males}

Twenty adult male Swiss mice weighing (20-30 g) obtained from the animal house of the national research center were used to evaluate the oxfendazole (MRL) genotoxicity in male cells. The animals were randomly divided into two groups and had food and water ad libitum. The first group was given distilled water orally and served as the control. The second group was orally given the dose of oxfendazole (MRL) daily for eight weeks. At the end of the time of drug administration, all animals were injected IP with a colchicine solution. Two hours later, the animals were sacrificed by cervical dislocation and the chromosomes 
of bone marrow cells and spermatocytes were prepared according to Yosida and Amano [9], Brewen and Preston [10].

\subsection{Assay of genotoxicity in females}

Adult male and adult virgin females of Swiss albino mice were maintained on feed and water ad libitum in the animal house of the national research center. Both male and female animals were divided into two groups. The animals of the first group were given distilled water orally and served as the control animals. The animals of the second group were orally given a dose of oxfendazole (MRL) for four weeks. After that, males and females were caged by ratio (1:1) according to the following groups:

Group I: control males and females.

Group II: treated males and control females.

Group III: control males and treated females.

Group IV: treated males and females.

Successful mating was determined by the presence of vaginal plugs on the next morning which was designed as day zero of pregnancy. Drug oral administration in the same manner continued until day 18 of pregnancy.

\subsection{Teratological examination}

On day 18 of gestation, ten pregnant females of each group were sacrificed by cervical dislocation. The uterine horns were opened and the numbers of alive, dead and resorbed fetuses were recorded according to Gleich and Frohberg [11]. The body weights of live fetuses were recorded just after dissection. Also the fetuses were externally examined to determine any deformities. For skeletal examination, fetal skeletons were prepared and stained in Alizarin red-S according to the method described by Weesner [12]. After staining, the skeletons were examined under the dissecting binocular microscope to detect any malformation in the bones of the axial and appendicular skeletons.

\subsection{Chromosome preparation}

The chromosomes of bone marrow cells of pregnant females were prepared by using the methodology of Yosida and Amano [9] and the chromosomes of fetal cells were prepared according to the method of Romagnano et al. [13].

The slides were stained with $10 \%$ Giemsa stain and 100 good metaphase spreads of each cell types for all animals were examined microscopically to analyze the different types of chromosomal aberrations.

\subsection{Biochemical analysis}

Total content of DNA, RNA, protein and enzymes in different tissues (liver, kidney, testes and embryos) of male and female mice were determined. DNA contents were determined according to Dische [14] using the diphenylamine method; DNA giving blue color was read using a spectrophotometer at $600 \mathrm{~nm}$. RNA content was determined by using the Orcinol reagent method according to Schneider [15] and read at $660 \mathrm{~nm}$. Protein content was determined according to Gomall et al. [16] and read at $545 \mathrm{~nm}$. Enzyme activities of the liver (GOT and GPT) were determined according to Reitman and Frankel [17] at $545 \mathrm{~nm}$.

\subsection{Statistical analysis}

Data of biochemical analysis and cytogenetical examination of males were analyzed by a paired- $t$-test. The data of the fetuses morphological examination and chromosome aberrations were analyzed statistically by using one way analysis of variance (ANOVA).

\section{RESULTS}

\subsection{Effect of oxfendazole maximum residue limit (MRL) in males}

The data of the present study indicated that oxfendazole (MRL) oral administration of male mice for eight weeks induced chromosome aberrations in bone marrow and spermatocyte cells as shown in Figures 1 


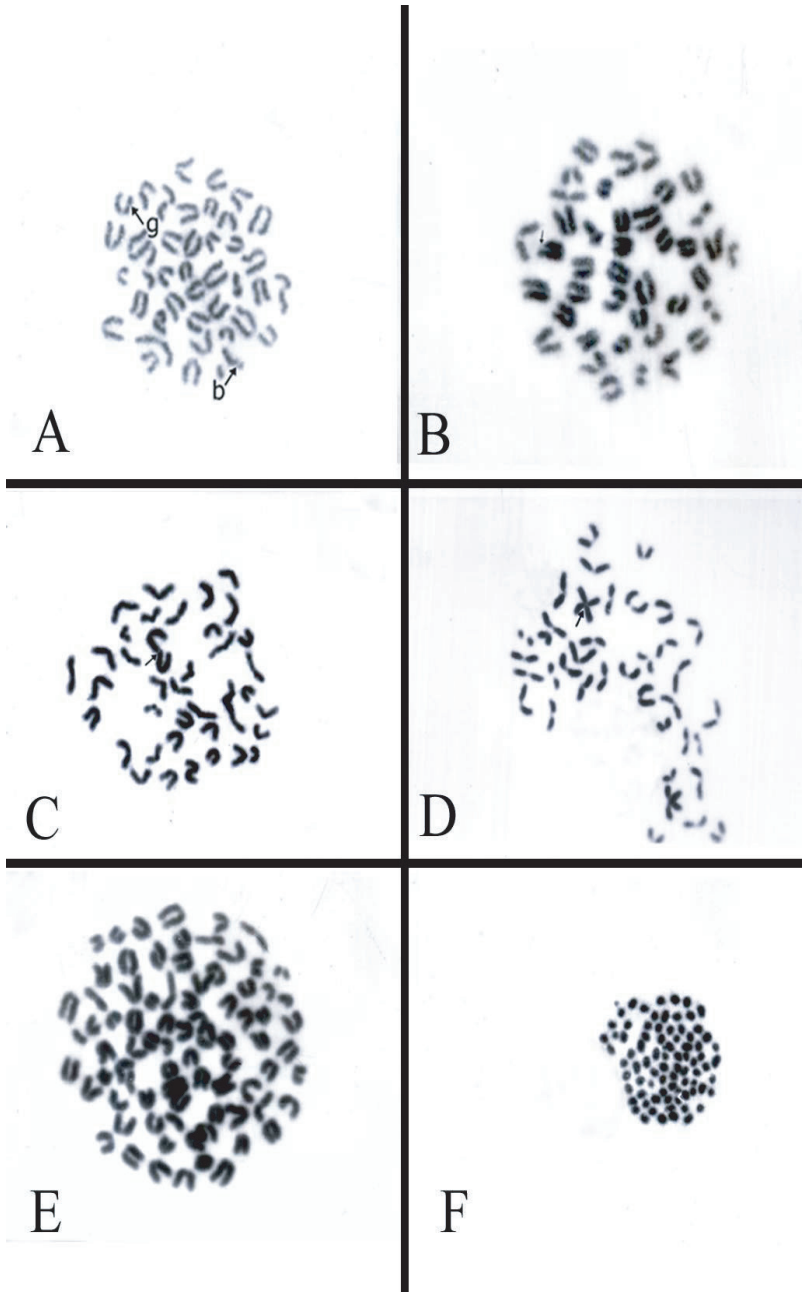

Figure 1. Different types of chromosomal aberrations induced by oxfendazole (MRL) in bone marrow cells: $(\mathbf{A})$ gap $(\mathrm{g})$ and break (b) (B) deletion (C) end to end association (D) centric fusion (E) polyploidy (F) endomitosis. and 2. Table I and Figure 3 illustrate the mean values and standard deviations of different types of chromosomal aberrations in bone marrow cells of control and oxfendazole (MRL) treated male mice. The data showed that oxfendazole caused a statistically significant increase in the mean values of the gaps, endomitosis, and centric fusions at $(P \leq 0.05)$ when compared with the control. The results also revealed that oxfendazole showed a statistically significant increase in the mean values of fragments, deletions, and end to end associations, polyploidy and total chromosomal aberrations at $(P \leq 0.01)$ than the control. However, the statistical analysis of the other individual chromosomal aberrations showed non significant differences between the mean values of the different treated groups and the control. Table II and Figure 4 demonstrate that oxfendazole (MRL) treated male mice showed a statistically significant increase in the mean values of autosomal univalent, $\mathrm{x}-\mathrm{y}$ univalent, aneuploidy and total chromosomal aberrations at $(P \leq 0.01)$ when compared with the control group, whereas, translocation, ring and polyploidy showed non significant differences. 


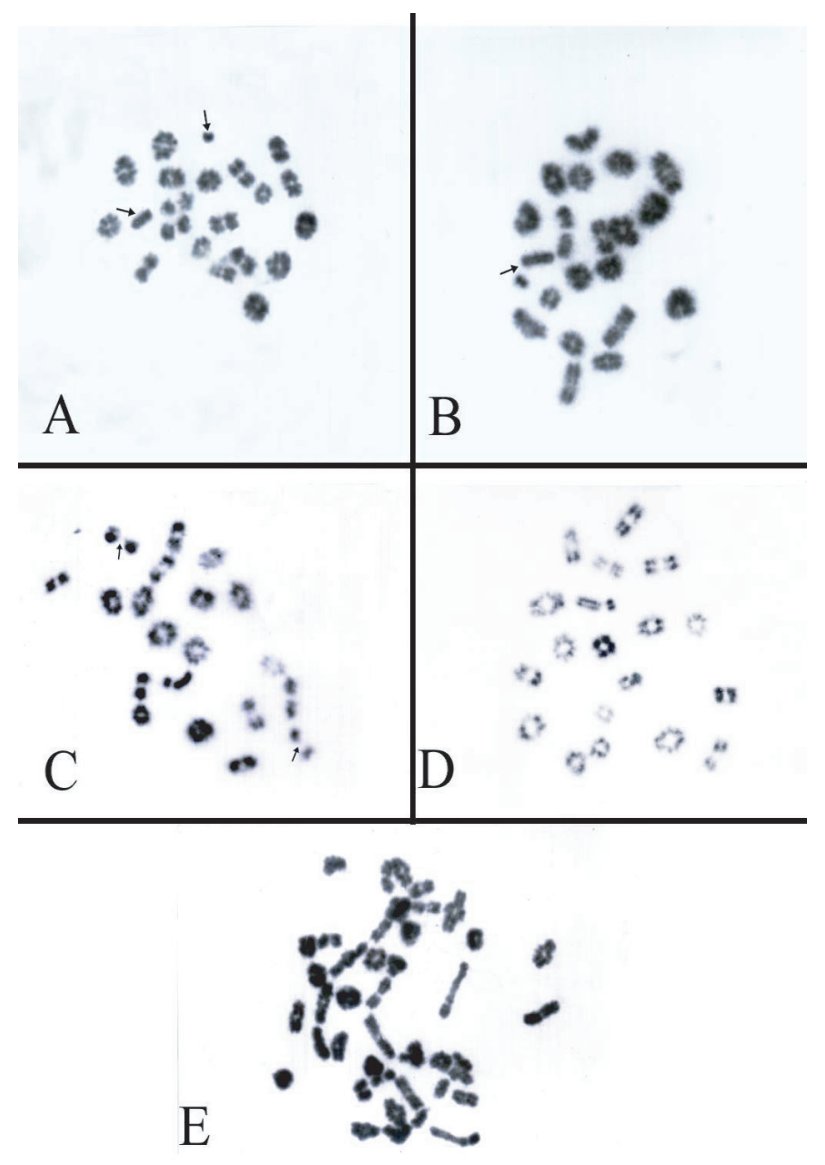

Figure 2. Different types of chromosomal aberrations induced by oxfendazole (MRL) in spermatocytes: (A) $x-y$ univalent (B) x-y univalent (C) autosomal univalent (D) hypoploidy (E) polyploidy.

\subsection{Effect of oxfendazole maximum residue limit $(M R L)$ in females}

The mean frequencies of different individuals and total chromosomal aberrations induced in female bone marrow cells of the treated group and the standard deviations are presented in Table III and Figure 5. The data showed that oxfendazole caused a statistically significant increase in the mean values of endomitosis, centric fusion, fragments, deletions, end to end associations, polyploidy and total chromosomal aberrations at $(P \leq 0.01)$ when compared with the control. Meanwhile, it showed a statistically significant increase in the mean values of the other types of chromosomal aberrations at $(P \leq 0.05)$.

\subsection{Effect of oxfendazole maximum residue limit (MRL) on fetal cells}

The data of Table IV and Figure 6 represent the mean values of different individual and total chromosomal aberrations induced by oxfendazole (MRL) in embryo cells. The results indicate that oxfendazole oral administration for males or females only induced a statistically significant increase in all individual and total chromosome aberrations in the cells of their embryos at $(P \leq 0.01)$ when compared with the embryos of control males and females. 


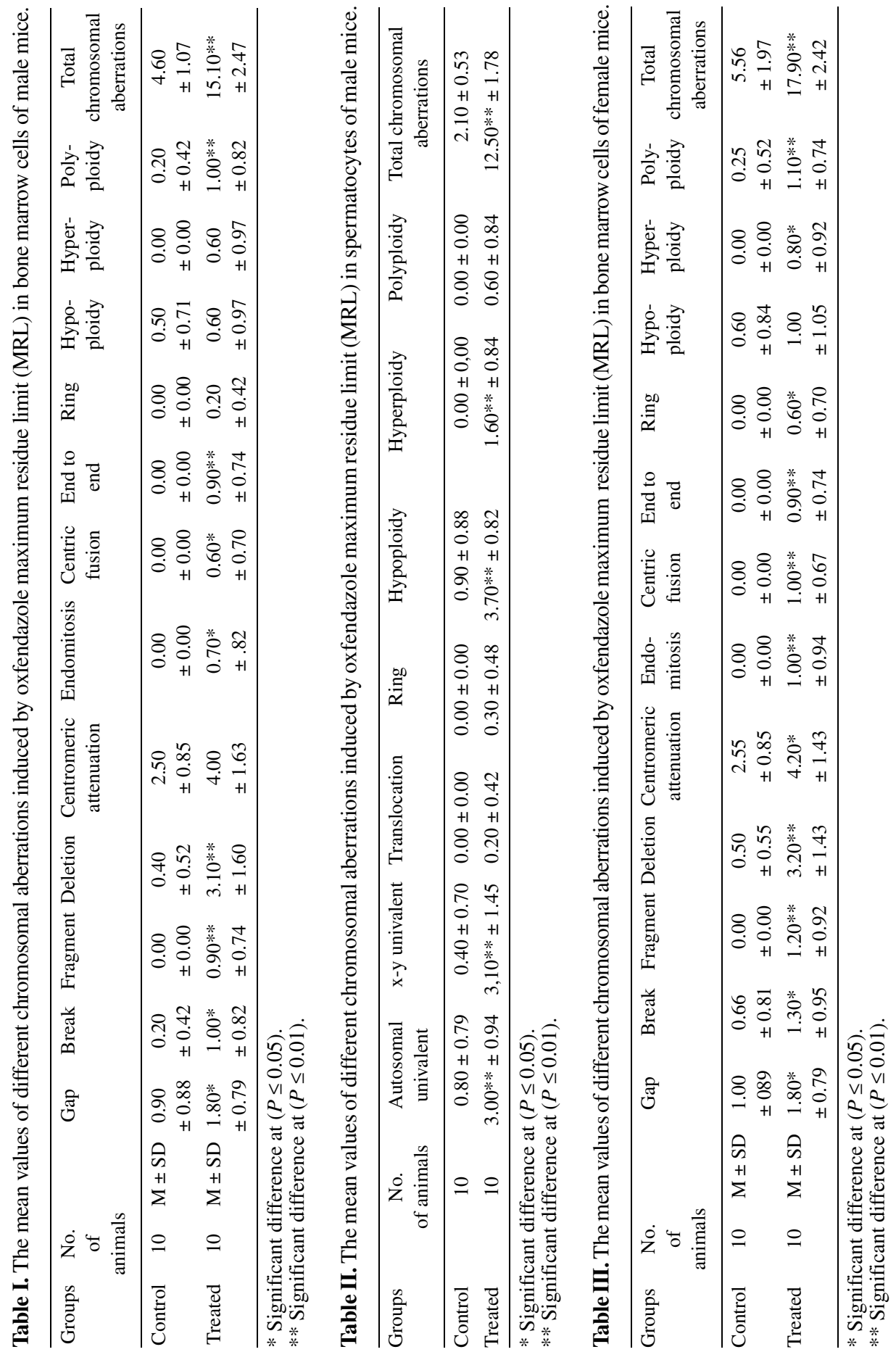




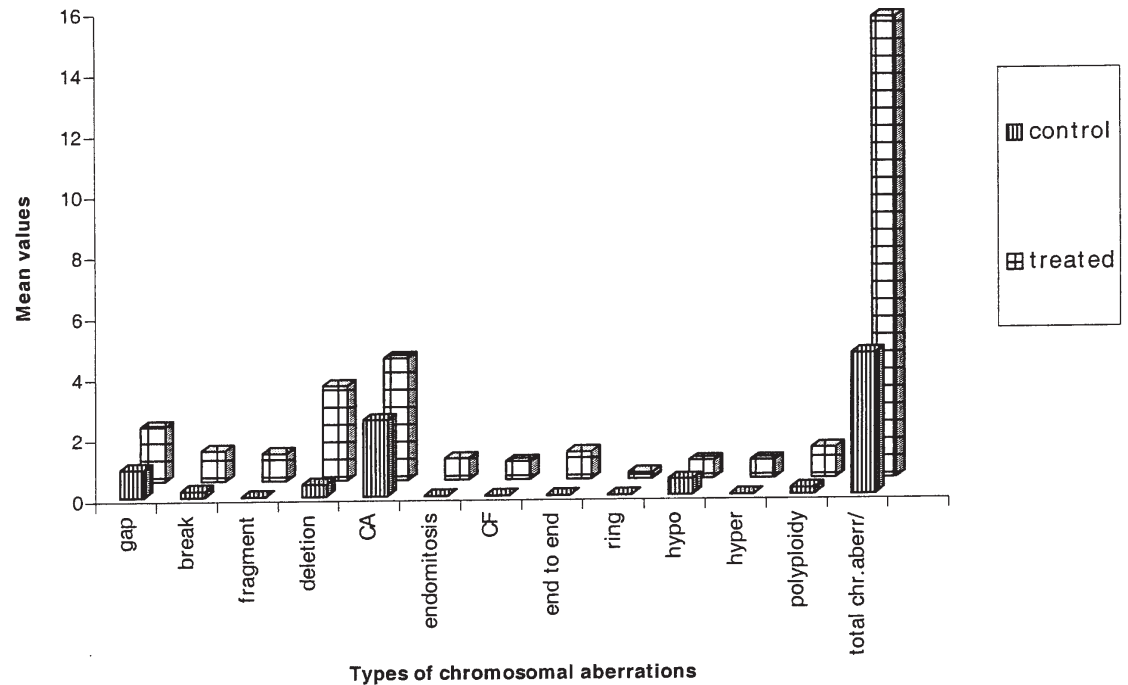

Figure 3. Effect of oxfendazole (MRL) on bone marrow cells of male mice.

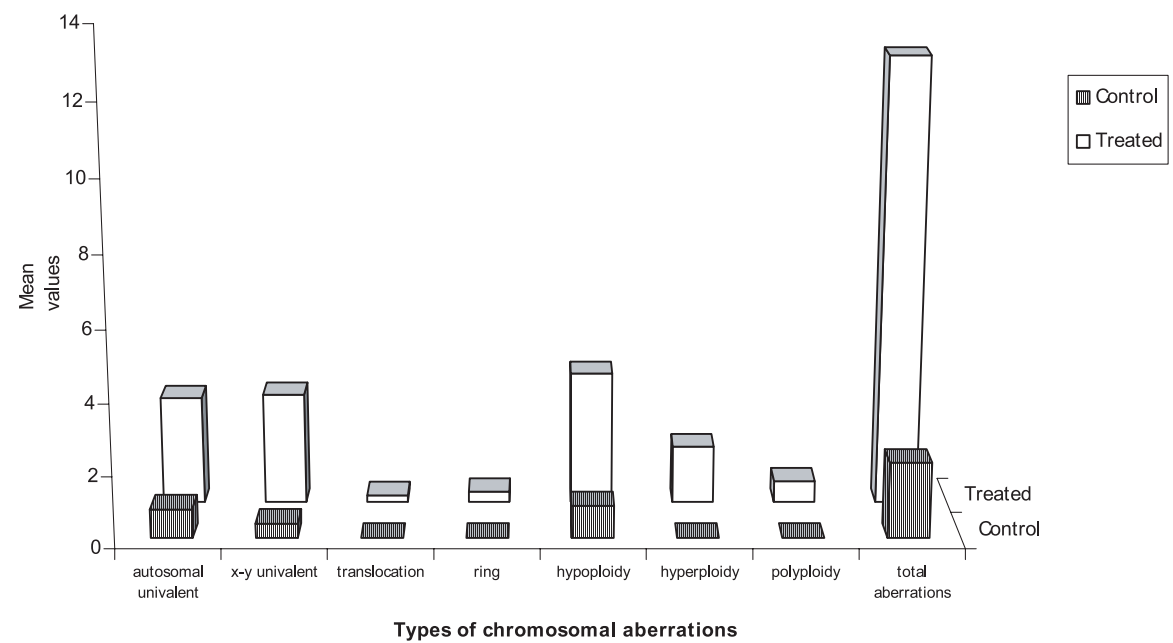

Figure 4. Effect of oxfendazole (MRL) on spermatocytes of male mice.

\subsection{Teratogenic effect of oxfendazole} maximum residue limits (MRL)

\subsubsection{External morphological examination}

The mean values of different teratogenic variables are tabulated in Table V and Fig- ure 7. The results showed that oxfendazole (MRL) induced a statistically significant decrease in the number of live fetuses in all groups at $(P \leq 0.01)$ when compared with the control, whereas, it induced a non significant increase in the number of resorbed fetuses (Fig. 8) in the groups in which males 


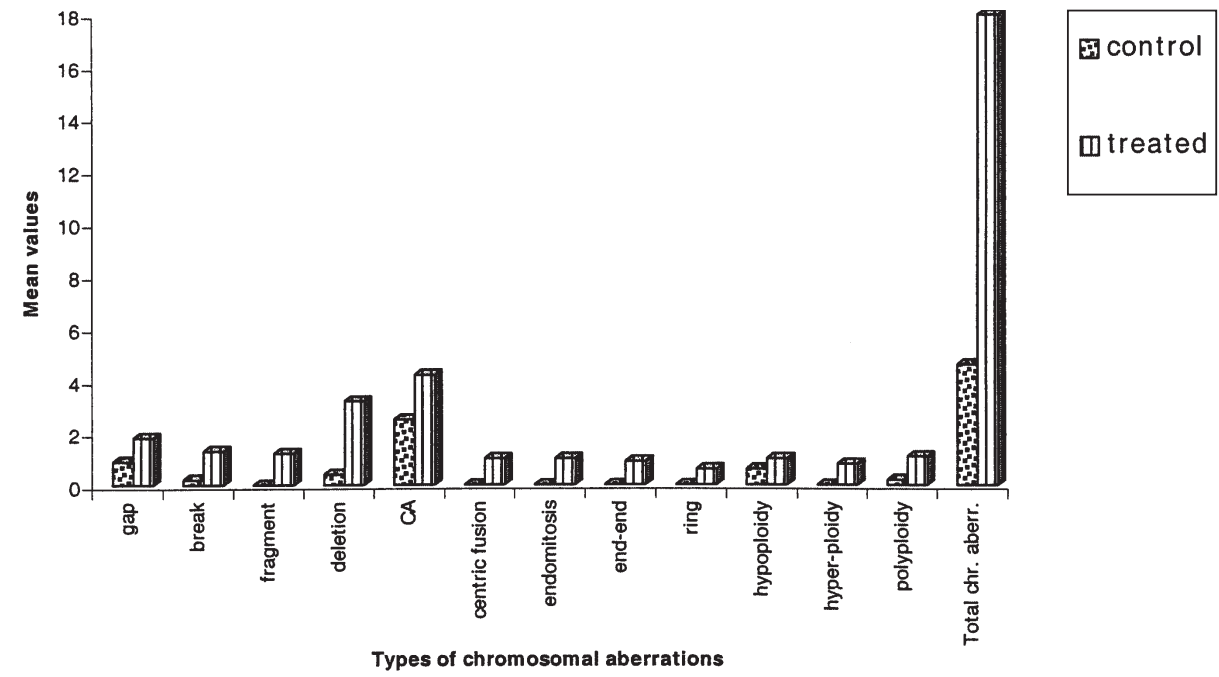

Figure 5. Effect of oxfendazole (MRL) on bone marrow cells of female mice.

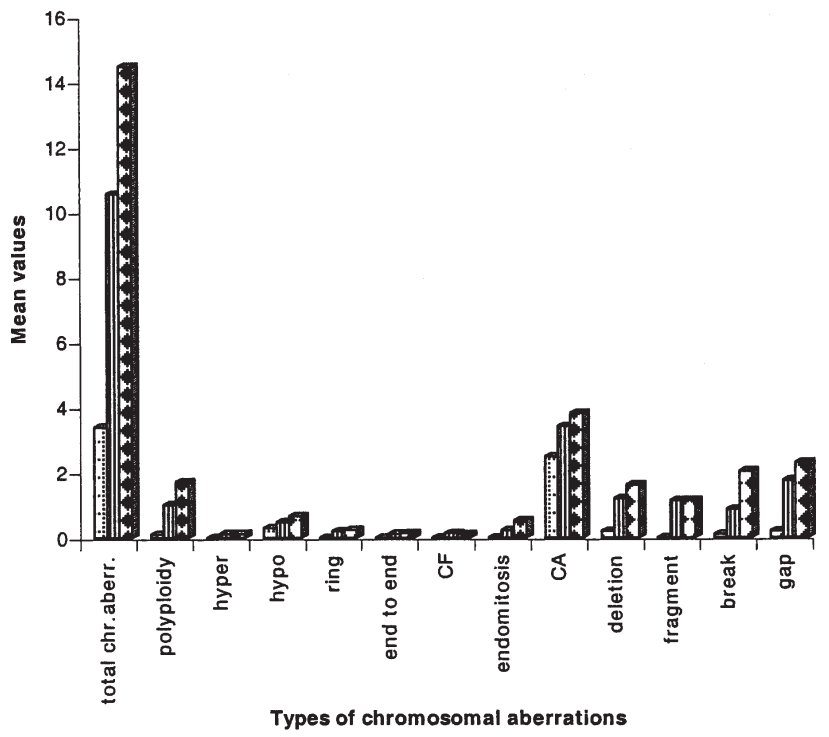

Figure 6. Effect of oxfendazole maximum residue limit (MRL) on embryo cells of all experimental groups.

or females were treated only. However, in the group of treated males and females, oxfendazole showed a statistically significant increase in the number of resorbed fetuses at $(P \leq 0.01)$. Since, all fetuses of this group were completely resorbed. Meanwhile, there was no significant difference between the number of hematoma (Fig. 9) 


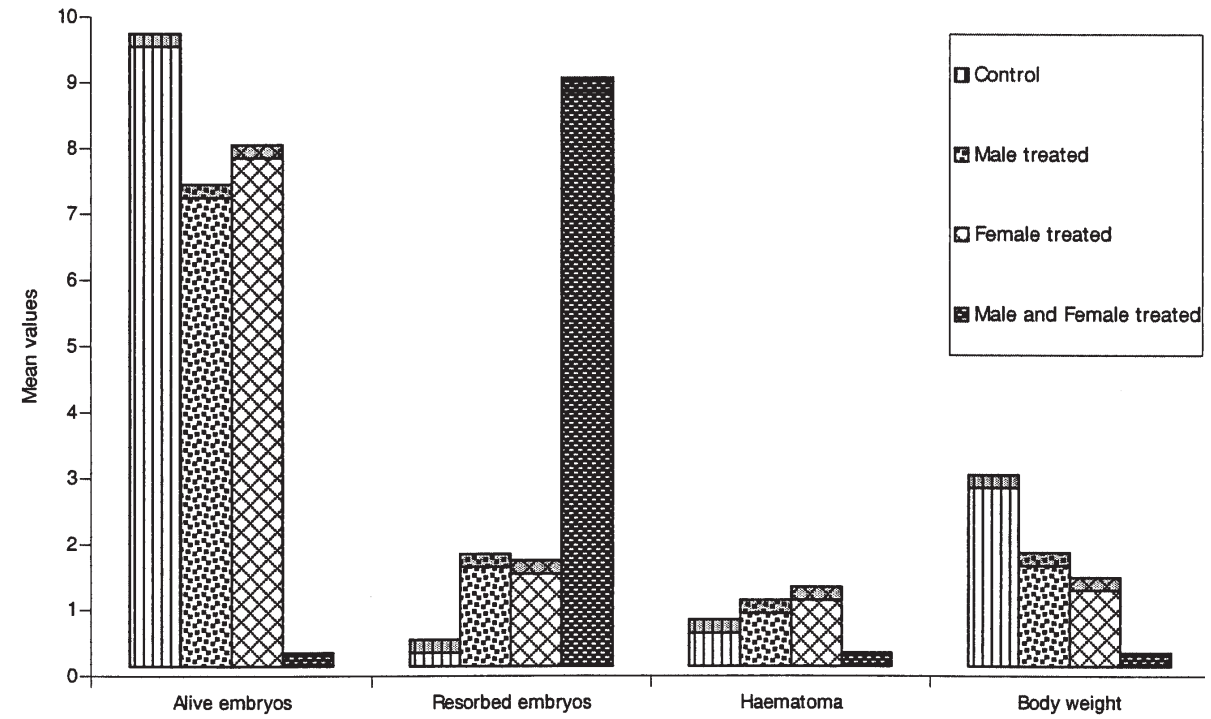

Figure 7. Teratogenic effect of oxfendazole (MRL) in all experimental groups.

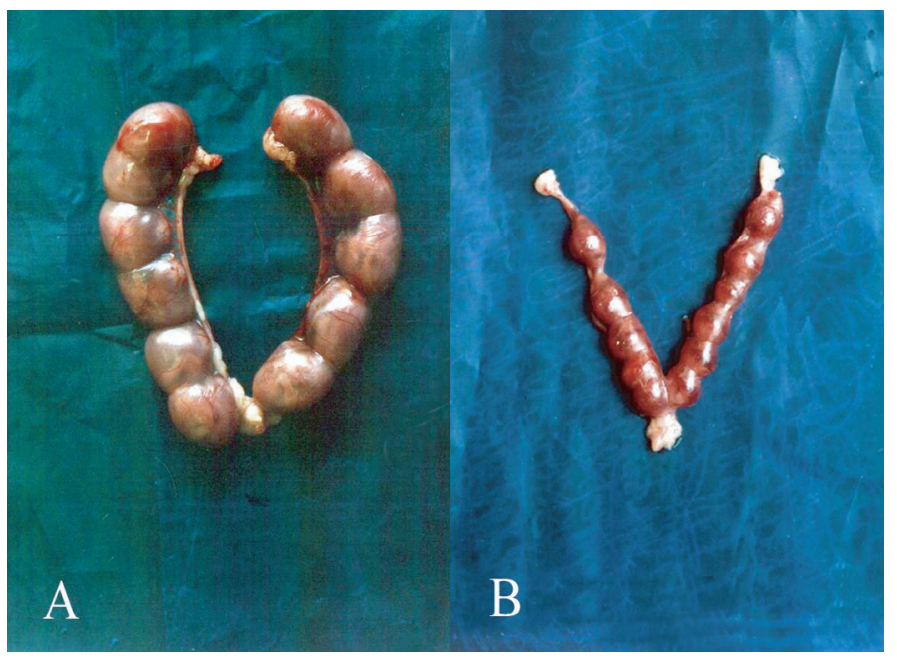

Figure 8. Photograph of the uterus of a control pregnant female $(\mathbf{A})$ and a uterus with resorbed embryos of an oxfendazole (MRL) treated female (B) on day 18 of gestation.

in all treated groups and the control. However, oxfendazole (MRL) showed a statistically significant decrease in the fetal body weights of all treated groups at $(P \leq 0.01)$ when compared with the untreated group.

\subsubsection{Skeletal examination}

Alizarin red-S stained 18th day of gestation oxfendazole treated male or female fetal skeletons showed an obvious decrease 
in the size and reduction in the ossification of fetal skeletons as compared to those of the control group. Sacral vertebrae showed severe lack of ossification and caudal vertebrae were completely non ossified. The bones of the pelvic girdle of the control fetuses, illium, ischium and pubis were well ossified, whereas in the skeletons of the oxfendazole (MRL) treated fetuses, the pubis bones were completely non-ossified and the ischium bones showed a lesser degree of ossification (Fig. 10).

\subsection{Biochemical results}

The data of biochemical studies on different parameters in all experimental tissues figure in Tables VI, VII and VIII. The data show that oxfendazole (MRL) affected

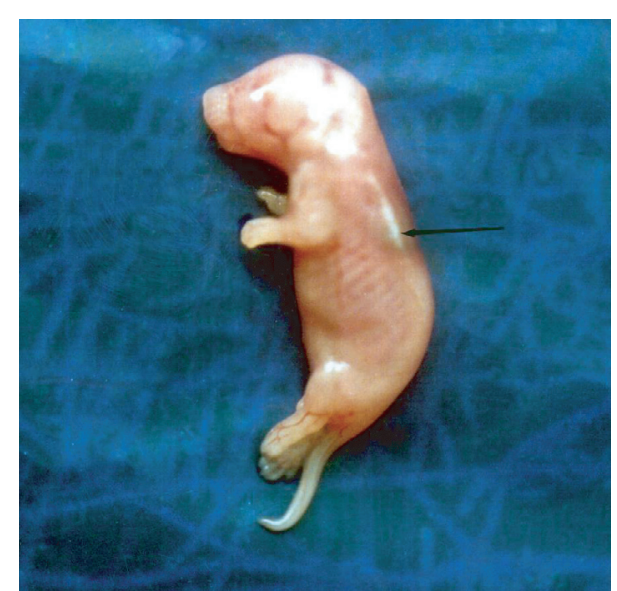

Figure 9. Photograph of oxfendazole (MRL) maternally treated embryo on day 18 of gestation showing an external Haematoma.

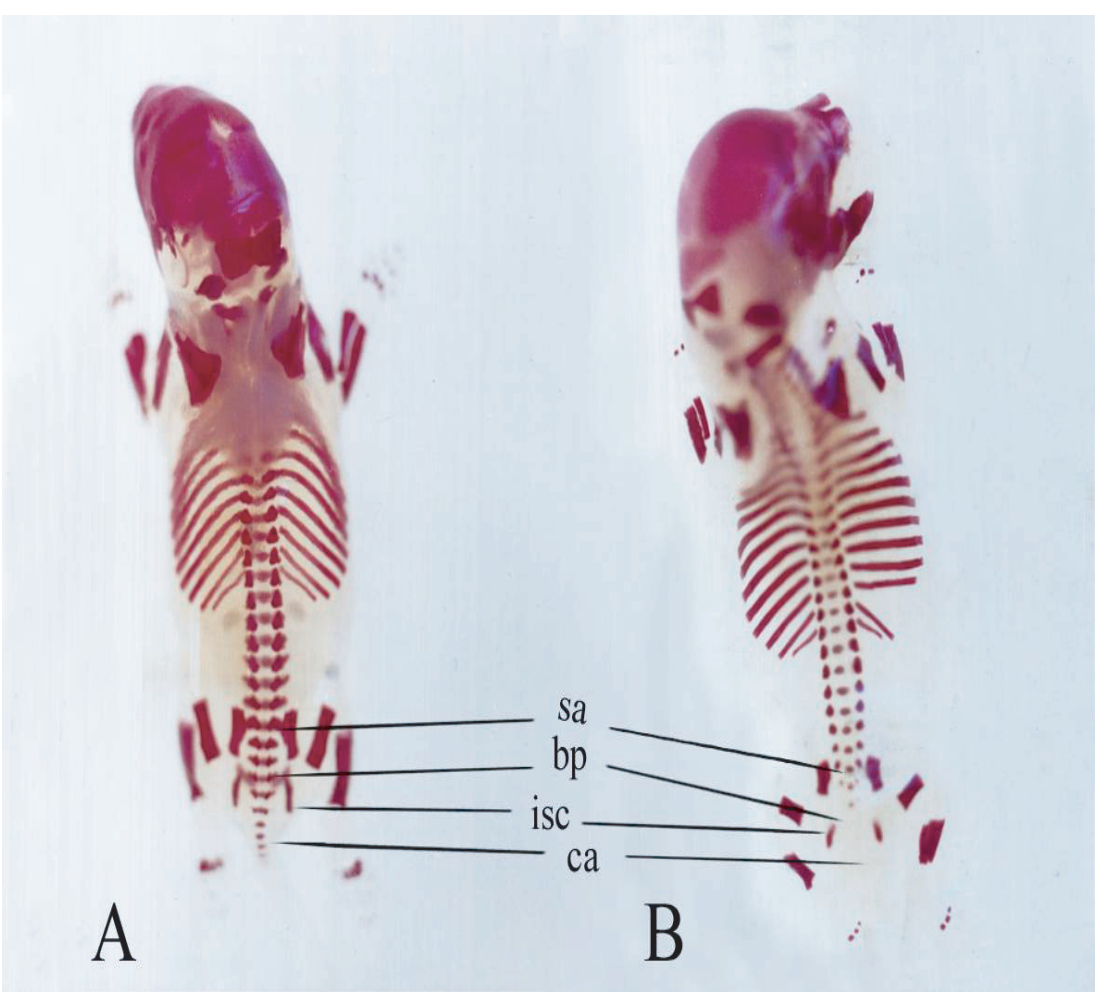

Figure 10. Photograph of fetal skeletons at day 18 of gestation showing (A) control fetus with well ossified bones (B) oxfendazole (MRL) maternally treated fetus showing complete non- ossification of sacral and caudal vertebrae (ca.v) and pubis (pb) bones of the pelvic girdle (alizarine S- red stain). 


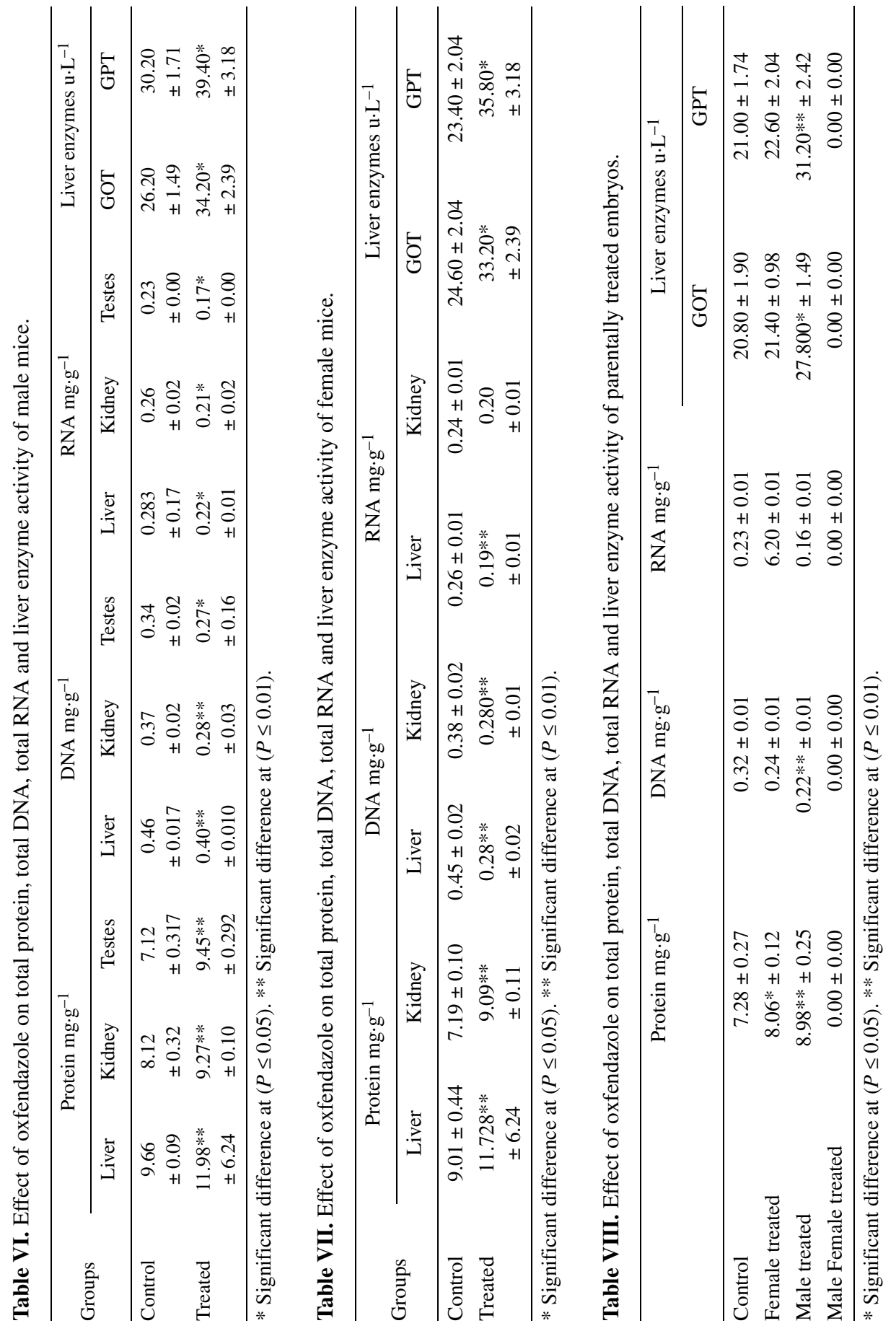




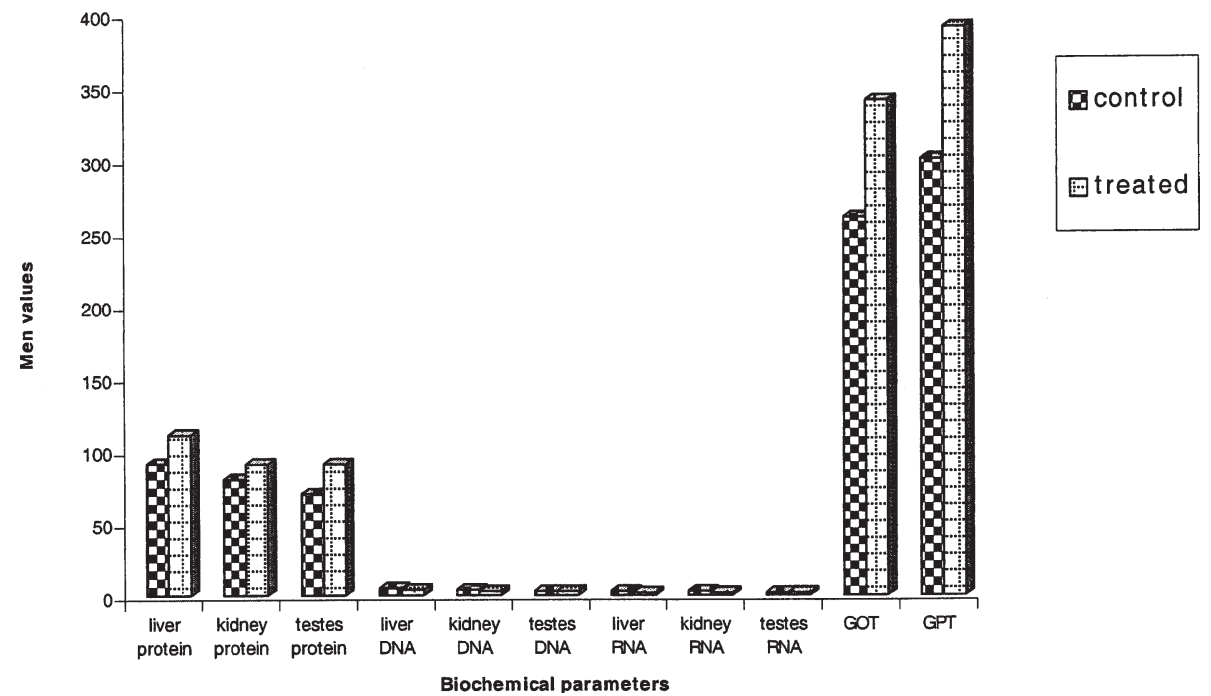

Figure 11. Effect of oxfendazole (MRL) on different biochemical parameters in male mice.

the liver, kidney, testes and embryo tissues and caused changes in all measured biochemical parameters of mice.

\subsubsection{Biochemical changes in males}

The data presented in Table VI and Figure 11 showed that oral administration of oxfendazole (MRL) caused a statistically significant increase in the total protein content of the liver, kidney and testes at $(P \leq$ $0.01)$ when compared with the control. However, the total content of DNA of the tissues was significantly decreased at $(P \leq$ $0.01)$ when compared to the control. Meanwhile, a statistically significant decrease in the level of total RNA content at $(P \leq 0.05)$ was observed. However, the levels of liver enzymes (GOT and GPT) of oxfendazole (MRL) male mice tissues were statistically significantly higher $(P \leq 0.05)$ than the control.

\subsubsection{Biochemical changes in pregnant females and their embryos}

The data of Tables VII and VIII, Figures 12 and 13 showed that the total
DNA and RNA content of the liver of oxfendazole (MRL) pregnant females and their embryos, were significantly decreased at $(P \leq 0.01)$ when compared with the control. The DNA content of the kidney tissues was statistically significant decrease at $(P \leq 0.05)$ when compared with the control. Whereas, RNA content did not show a significant change. A significant increase at $(P \leq 0.01)$ in the protein content of treated pregnant female tissues and in embryos obtained from them was detected. Also, oxfendazole (MRL) significantly increased the liver enzyme (GOT and GPT) content of females and their embryos at $(P \leq 0.01)$ as compared with the control.

\section{DISCUSSION}

The extensive use of veterinary drugs in food producing animals can cause the presence of drug residues in food [7]. Certain drugs can be carried over into the milk of lactating animals or deposited in the tissues of animals intended for slaughter [6]. A Maximum Residue Limit is an amount of 


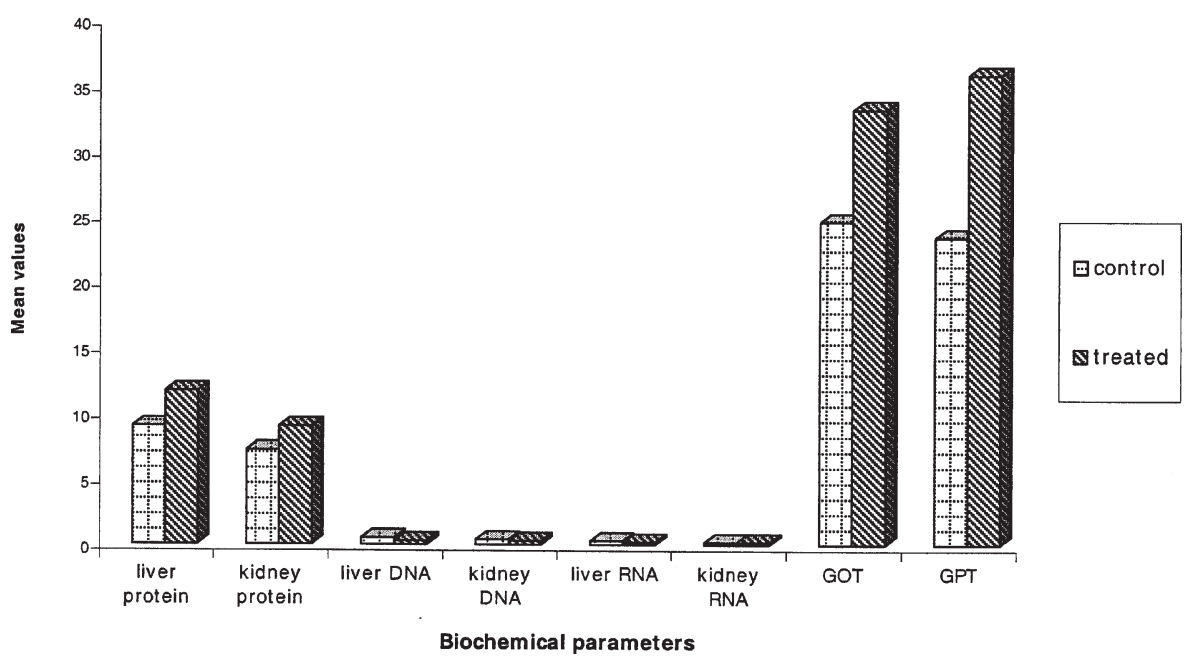

Figure 12. Effect of oxfendazole maximum residue limit (MRL) on different biochemical parameters in female mice.

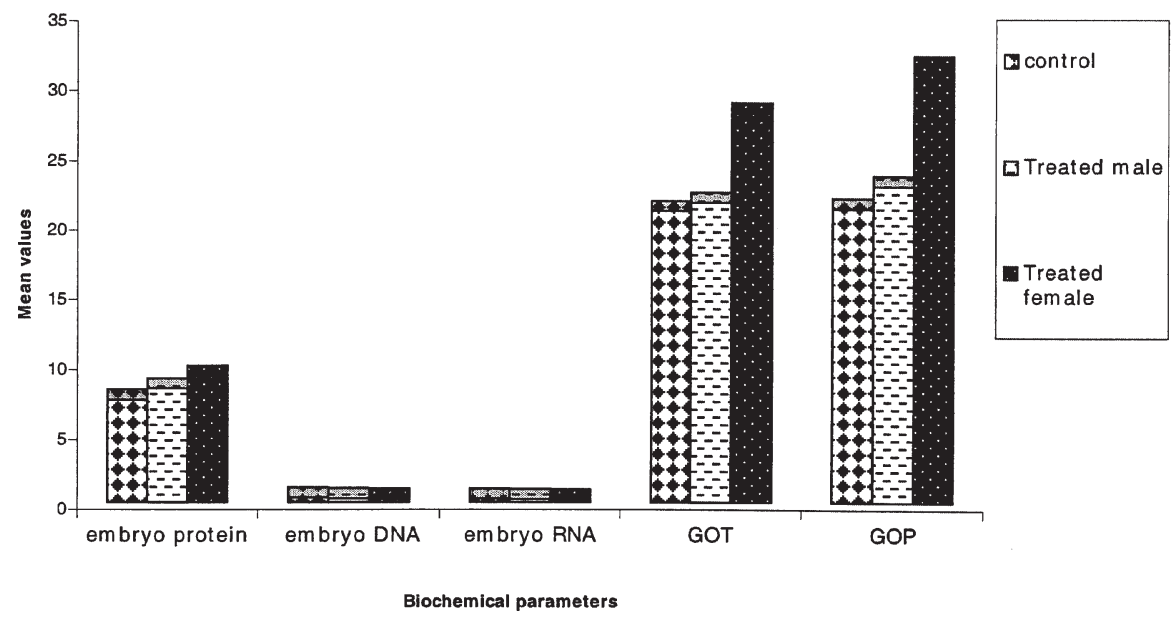

Figure 13. Effect of oxfendazole maximum residue limit (MRL) on different biochemical parameters in embryo tissues.

residue that could remain in the tissue or food product derived from a food-producing animal that has been treated with a veterinary drug. This residue is considered to pose no adverse health effects if ingested daily by humans over a lifetime [18]. In recent years, there has been increasing concern that drugs may present a potential hazard to mankind by causing gene mutation or chromosome aberrations. Genetic alterations in somatic cells can include cell death or transform into malignancy. Genetic 
alterations in germ cells lead to reproductive failure or genetic disorder in subsequent generations [8]. In the present study, oral administration of oxfendazole (MRL) induced a statistically significant increase in the frequencies of chromosomal aberrations in all tested cell types. This means that anthelmintic oxfendazole has a possible genotoxic activity. Crebelli [19] reported that genotoxicity of benzimidazoles may appear in DNA damage or involving multiple interactions with non-DNA targets. Ardito et al. [20]) indicated that higher non toxic concentrations of Thiabendazole cause an increase in the sister chromatid exchange frequency in lymphocyte culture. The results of the present study indicate that oxfendazole induced a statistically significant increase in the frequencies of polyploidy in bone marrow and spermatocyte cells of male mice and also in embryo cells. The literature reported that several anthelmintic drugs have been evaluated for genotoxicity. Crebelli et al. [21], Leopardi et al. [22], Natarajan et al. [23], Parry and Sors [24], Mailhes et al., [25] and Adler et al. [26] demonstrated that thiabendazole is capable of inducing numerical chromosomal changes such as aneuploidy and polyploidy. At toxic doses, thiabendazole increases the frequency of aneuploid in oocytes that impair ovulation. Also, Schmid et al. [27] showed that thiabendazole increases the frequency of aneuploidy induction in the sperm of treated male mice. Barale et al. [28] studied the cytogenetic effects of three benzimidazoles, i.e., benomyl, methyl thiophanate and methyl 2-benzimidazolecarbamate (MBC), in mouse bone marrow cells. Benomyl and MBC significantly induce micronuclei and aneugenic flubendazole causes a dose and time dependent induction of polyploidy in Chinese hamster lung cells. Mebendazole interacting with tubulin interferes with the assemblage of the mitotic apparatus in the parasite cells, thus causing a possible genotoxic activity leading to chromosomal malsegregation [29]. Also, Okamura et al. [30] suggested that oxfendazole induces apoptosis of meiotic spermatocytes, most probably due to disruption of the microtubules, and degeneration of the Sertoli cells. Uppala et al. [31] indicate that chemicals can induce cellular and chromosomal alterations, inducing early events in carcinogenesis. This means that oxfendazole genetic alteration in somatic cells may lead to malignancy. Our findings indicate that oral administration of oxfendazole (MRL) to parents for eight weeks produced developmental toxicity in their embryos. This toxicity appeared in the decrease in embryo body weights and the less ossified skeletons. These results were in agreement with Delatour et al. [32] and Delatour [33] indicating that benzimidazole anthelmintic oxfendazole, the active metabolite of fenbantel, is embryotoxic and teratogenic in the rat. Scholz and Baeder [34] demonstrated that Fenbendazole showed fetotoxicity in rats and rabbits dosed by gavage. Embryotoxicity was observed in the form of an increase in the frequency of occurrence of the 13 th ribs and delayed ossification of cranial bones in rabbits given a dose of $63 \mathrm{mg} \cdot \mathrm{kg}^{-1}$ of body weight/day. Lankas et al. [35] reported that thiabendazole is foetotoxic in mice. Delatour et al. [36] reported that there is possible correlation between embryotoxicity and the plasma levels of identified embryotoxic metabolites, but not with the levels of fetal tissue bound drug metabolites. Whittaker and Faustman $[37,38]$ reported that the benzimidazole anthelmintic should be considered as potential developmental toxicants. Since, they inhibit cell growth and differentiation of micromass culture of rat embryo midbrain and limb bud cells. In agreement with our result, Capece et al. [39], Navarro et al. [40] reported that benzimidazole induces a significant increase of resorptions, a decrease of fetal body weights and an increase in skeletal malformation. Mantovni [41] and Teruel et al. [42] indicated that the benzimidazole anthelmintic, albendazole, shows a dose related increase in embryolethality, growth reduction and a reduction in the ossification process in the rat. Cristofol et al. [43] studied the 
disposition of albendazole and its metabolites, albendazole sulfoxide and sulfone in the pregnant rat. The results indicated that the presence of albendazole and its metabolites in the amniotic sacs and embryos at concentration were higher than that in the plasma at the same times. A significant correlation was found between the rate of developmental toxicity and metabolite concentration. Also, El-Makawy [44] mentioned that embryotoxicity is mainly the result of chromosome damage leading to a loss of genetic material. The data of the biochemical study in the present work show that oral administration of oxfendazole (MRL) caused a significant increase in the total protein content of the liver, kidney and testes and decrease in the total content of DNA and RNA of tissues. Baliharova et al. [45] indicated that all benzimidazoles provoke an increase in the protein level of rat hepatocytes. Also, oxfendazole (MRL) significantly increased the liver enzyme (GOT and GPT) content. This result was in agreement with that of Tada et al. [46] who reported that thiabendazole showed an increase in concentrations of GOT and GPT in male and female mice. Karmakar et al. [47] mentioned that hepatic enzymes significantly increased along with an increased percentage of chromosome aberrations in the bone marrow. The results therefore strongly suggest that oxfendazole exerts genotoxicity in male and female mice. Also, oxfendazole exhibits embryotoxicity including teratogenicity. We can conclude that embryo developmental toxicity of oxfendazole may be a result to the increase in the frequencies of different chromosomal aberrations and biochemical changes. So, we must increase the attention to the potential risk of oxfendazole residues on human beings and should stress the need for careful control to ensure the adherence to the prescribed withdrawal time of this drug.

\section{REFERENCES}

[1] Delatour P, Parish R. Drug residues in animals. Ed Rico AG, Academic Press, New York, USA 1986.
[2] Klee S, Baumung I, Kluge K, Ungemach FR, Horne E, O Keeffe M, De Angelis I, Vignoli AL, Zucco F, Stammati A. A contribution to safety assessment of veterinary drug residues: in vitro/ex vivo studies on the intestinal toxicity and transport of covalently bound residues. Xenobiotica 1999, 29: 641-654.

[3] FAO/WHO Expert Committee on Food Additives, Evaluation of certain veterinary drug residues in food, Fiftieth report of the joint World Health Organ Tech Rep Ser 1999, 888: $1-95$.

[4] Prichard RK, Ranjan S. Anthelmintics. Vet Parasitol 1993, 46: 113.

[5] Rose MD, Bygrave J, Farrington WH, Shearer $\mathrm{G}$. The effect of cooking on veterinary drug residues in food, Part 8. Benzylpenicillin. Analyst 1997, 122: 1095-1099.

[6] McGrane M, Okeeffe M, Smyth MR. Multiresidue analysis of penicillin residues in porcine tissue using matrix solid phase dispersion. Analyst 1998, 123: 2779-2783.

[7] Galer DM, Monro AM. Veterinary drugs no longer need testing for carcinogenicity in rodent bioassays. Regulatory Toxicology and Pharmacology 1998, 28: 115-123.

[8] Nagalakshmi K, Tong-man O. Occupational exposure to genotoxic agents. Mut Res 1999, 437: 175-194.

[9] Yosida TH, Amano K. Autosomal polymorphic in laboratory bred and Wild Norway rats Rattus norvegicus, found in Misima. Chromosoma 1965, 16: 658-666.

[10] Brewen GJ, Preston JR. Analysis of chromosome aberrations in mammalian germ cells. Chemical Mutagenesis 1978, 5: 127-150.

[11] Gleich J, Frohberg H. General teratological technique. In: Methods in prenatal toxicology, George Thieme Publishers, Stuttgart, 1977.

[12] Weesner FM. General zoological microtechniques. Scientific Book Indian Ed, Agency Calcutta, 1968, p 100-101.

[13] Romagnano A, King AW, Richer CL, Perrone MA. A direct technique for the preparation of chromosomes from early equine embryos. J Gent Cytol 1985, 27: 365-369.

[14] Dische Z. Color reaction of nucleic acid components. In: Chargaff E, Davidson JM (Eds), The nucleic acids, vol 1, Academic press, New York, 1955, 270-284.

[15] Schneider WC. Determination of acid in tissues by pentose analysis. In: Colowick SP, Kaplan NO (Eds), Method enzymology, Academic press, New York, 1957, p 680-684. 
[16] Gomall AC, Bardaawill CJ, David MM. Protein clometric method. J Biol Chem 1949, 177: 751-760.

[17] Reitman S, Frankel S. Got and Gpt colometric method. Am J Clin Path 1957, 28: 26-30.

[18] Kirkpatrick D. The veterinary drugs directorate to discuss EXTRA-LABEL drug use in Halifax. Can Vet J 2002, 43: 425-426.

[19] Crebelli R, Thershold-mediated mechanisms in mutagenesis: implications in the classification and regulation of chemical mutagens. Mut Res 2000, 464: 129-135.

[20] Ardito G, Bramanti B, Bigatti P, Lamberti L, Dolara P. Cytogenetic effect of thiabendazole and diphenylammine on cultured human lymphocytes; sister chromatid exchanges and cell cycle delay. Boll Soc Ital Biol Sper 1996, 72 : 171-178.

[21] Crebelli R, Conti G, Conti L, Carere A. In vitro studies with nine known or suspected spindle poisons: results in tests for chromosome malsegregation in Aspergillus nidulans. Mutagenesis 1991, 6: 131-136.

[22] Leopardi P, Zijno A, Bassani B, Pacchierotti F. In vivo studies on chemically induced aneuploidy in mouse somatic and germinal cells. Mut Res 1993, 287: 119-130.

[23] Natarajan AT, Duivenvoorden WC, Meijers M, Zwanenburg TS. Induction of mitotic aneuploidy using chinese hamster primary embryonic cells. Test results of 10 chemicals. Mut Res 1993, 287: 47-56.

[24] Parry J.M, Sors A. The detection and assessment of the aneugenic potentials of environmental chemicals. The European Community Aneuploidy project. Mut Res 1993, 287: 3-15.

[25] Mailhes JB, Young D, Aardema MJ, London SN. Thiabendazole-induced cytogenetic abnormalities in mouse oocytes. Environ Mol Mutagen 1997, 29: 367-371.

[26] Adler ID, Schmid TE, Baumgartner A. Induction of aneuploidy in male mouse germ cells detected by the sperm-FISH assay: a review of the present data base. Mutat Res 2002, 504: 173-182.

[27] Schmid TE, Xu W, Adler ID. Detection of aneuploidy by multicolor FISH in mouse sperm after in vivo treatment with acrylamide, colchicine, diazepam or thiabendazole. Mutagenesis 1999, 14: 173-179.

[28] Barale R, Scapoli C, Meli C, Casini D, Minunni M, Marrazzini A, Loprieno N, Barrai I. Cytogenetic effects of benzimidazoles in mouse bone marrow. Mut Res 1993,300: 15-28.
[29] De la Torre RA, Espinosa-Aguirre JJ, Cortinas de Nava C, Izquierdo T, Moron F. Genotoxic activity of menbendazole in Aspergillus nidulans. Mut Res 1994, 305: 139-144.

[30] Okamura M, Watanabe T, Kashida Y, Machida N, Mitsumori K. Possible mechanisms underlying the testicular toxicity of oxfendazole in rats. Toxicol Pathol 2004, 32: 1-8.

[31] Uppala PT, Roy SK, Tousson A, Barnes S, Uppala GR, Eastmond DA. Induction of cell proliferation, micronuclei and hyperdiploidy/ polyploidy in the mammary cells of DDT- and DMBA-treated pubertal rats. Environ Mol Mutagen 2005, 46: 43-52.

[32] Delatour P, Parish RC, Gyurik RJ. Albendazole: a comparison of relay embryotoxicity with embryotoxicity of individual metabolites. Ann Rech Vet 1981, 12: 159-167.

[33] Delatour P. Some aspects of the teratogenicity of veterinary drugs. Vet Res Commun 1983, 7: $125-131$.

[34] Scholz D, Baeder O. A teratogenicity test of HOE 881 with oral administration in yellowsilver rabbits. Hoechst-Roussel unpublished report, submitted to WHO by Hoechst AG, Frankfurt am Main, Germany, 1973.

[35] Lankas GR, Nakatsuka T, Komatsu T, Matsumoto $\mathrm{H}$. Developmental toxicity of orally administered thiabendazole in ICR mice. Food Chem Toxicol 2001, 39: 367-374.

[36] Delatour P, Garnier F, Benoit E, Longin C. A correlation of toxicity of albendazole and oxfendazole with their free metabolites and bound residues. J Vet Pharmacol Ther 1984, 7: 139-145.

[37] Whittaker SG, Faustman EM. Effects of albendazole and albendazole sulfoxide on cultures of differentiating rodent embryonic cells. Toxicol Appl Pharmacol 1991, 109: 73-84.

[38] Whittaker SG, Faustman EM. Effects of benzimidazole analogs on cultures of differentiating rodent embryonic cells. Toxicol Appl Pharmacol 1992, 113: 144-151.

[39] Capece BP, Navarro M, Arcalis T, Castells G, Toribio L, Perez F, Carretero A, Ruberte J, Arboix M, Cristofol C. Albendazole sulphoxide enantiomers in pregnant rats embryo concentrations and developmental toxicity. Vet $\mathbf{J}$ 2003, 165: 266-275.

[40] Navarro M, Canut L, Carretero A, Cristofol C, Perez-Aparicio FJ, Arboix M, Ruberte J. Developmental toxicity in rat fetuses exposed to the benzimidazole netobimin. Reprod Toxicol 1999, 13: 295-302. 
41] Mantovani A. The role of multigeneration studies in safety assessment of residues of veterinary drugs and additives. Ann Ist Super Sanita 1992, 28: 429-435.

[42] Teruel MT, Felipe AE, Solana HD, Sallovitz JM, Lanusse CE. Placental and fetal toxicity of albendazole sulphoxide in Wistar rats. Vet Hum Toxicol 2003, 45: 131-136.

[43] Cristofol C, Navarro M, Franquelo C, Valladares JE, Carretero A, Ruberte J, Arboix M. Disposition of netobimin, albendazole and its metabolites in the pregnant rats developmental toxicity. Toxicol Appl Pharmacol 1997. 144: 56-61.

[44] El-Makawy A. Mutagenic and teratogenic studies induced by anticancer (cisplatinum) in rat embryos. A Thesis submitted for the fulfillment of PhD degree in science, 1998.

[45] Baliharova V, Velik J, Lamka J, Balarinova R, Skalova L. The effects of albendazole and its metabolites on hepatic cytochromes P450 activities in mouflon and rat. Res Vet Sci 2003, 75: 231-239.

[46] Tada Y, Fujitani T, Yoneyama M. Subchronic toxicity of thiabendazole (TBZ) in ICR mice. Food Chem Toxicol 1996, 34: 709-716.

[47] Karmakar R, Banerjee A, Datta S, Chatterjee $\mathrm{M}$. Influence of cadmium intoxication on hepatic lipid peroxidation, glutathione level, and glutathione S-transferase and gammaglutamyl transpeptidase activities: correlation with chromosome aberrations in bone marrow cells. J Environ Pathol Toxicol Oncol 1999, 18: $277-287$. 